\title{
Impact of financing decisions ratios on firm accounting-based performance: evidence from Jordan listed companies
}

\author{
Feras Izzat Kasasbeh* ${ }^{*}$
}

\begin{abstract}
The impacts of financing decision ratios on a firm's accounting-based performance are essentially associated with particular data. For this purpose, firm size, firm age, and leverage are taken into account as control variables. The past studies have been reviewed to find gaps, which seemed to incorporate worn-out methods of research, and the inability of past researchers to inculcate firm accounting-based performance while measuring a firm's overall performance. So, data from 40 listed Jordan listed firms from the year 2007 have been collected, and 200 observations are made. The researcher also collected data from the website of the World Bank regarding these firms. It is employed by the generalized movement technique method to avoid heteroscedasticity, autocorrelation, and potential endogenous problems. The study results showed that the impacts of total debt to total assets and short-term debt to total assets are significant and negative on return on assets and return on equity. However, the impacts of long-term debt to total assets are significant and flattering on both return on assets and return on equity. The research has implications for the higher authorities and management to enhance the quality of their financial structure. In contrast, that research has some limitations because of employing a small number of factors to study the impacts of financing decision ratios.
\end{abstract}

Keywords: Financing decisions ratios, Firm accounting-based performance, Jordan

\section{Introduction}

The financial crisis worldwide resulted in several damages to many countries. It has particularly affected those countries which were dependant on their export and foreign investment for their economic growth. In the same line, the Jordan economy and its financial system are not excluded from the same global recession scenario, a different financial crisis. Along with that crisis and challenges came along opportunities that enabled the firms to improve their systems, adaptability, and competitiveness [17]. Financial decisions have always been and always will be an essential part of the structure of a firm. As the matter of fact, the financial aspect affects the firm's presence

*Correspondence: fkasasbeh@ut.edu.sa

Administrative Sciences Department, Community College, University of Tabuk, Tabuk 71491, Saudi Arabia and the future of the firm in the same way. The financial aspect offers the firm the primary keys to obtain all of its goals and expected profit [19]. Financing decisions show the portion of assets that are a result of taking debt and the assets that have been raised from the invested capital.

Moreover, the financing decisions foster the firm in maximizing its output from the input given in the form of debt or equity. Many of the financial decisions favor the fact that a company must carry on its operations with a combination of debt and Equity [23]. After the global financial crisis, the financial stability reports and decisions helped the firms make moves that were significant in improving the total assets of the form supported by debt. That was the way used by firms to get out of that global crisis. The debt ratio of a firm shows the associated risk to it. Hence, if a wrong financing decision is made, it 
can cause major financial instability which may lead the firm toward destructive operations.

In contrast, if those financial decisions are taken with significant consideration, they might result in a high level of performance and profitability [2]. There is no doubt that several studies have empirically examined the relationship between financing decisions and a firm's performance. In the previous studies, the relationship between financing decisions and firm accounting-based performance has not been focused [18]. Most of the studies that have been done on this topic are conducted in highly developed and well-settled countries whereas the researchers of underdeveloped countries have not gotten a chance to research the same factors in their firms in the same way [13]. The developed countries have the necessary resources for authentic research on the impacts of financial decisions on accounting-based performance (Abubakar \& Management, 2015). The researchers have not fully discovered yet how the financial decisions ultimately impacts a firm's performance that the managers or higher authorities take. Hence, there is no possibility shortly that the researchers will be able to identify how much the financial decisions impacts the accountingbased performance of a firm. In this study, the researcher has the aim:

- To know about the impacts of total debt to total assets on return on assets

- To know the impacts of long-term debt to total assets on return on assets

- To know the impacts of short-term debt to total assets on return on assets

- To know about the impacts of total debt to total assets on return on equity

- To know the impacts of long-term debt to total assets on return on equity

- To know the impacts of short-term debt to total assets on return on equity.

The researcher has also taken firm size, firm age, and leverage as control variables. The latest tools and techniques for data collection and data analysis have been used for this research. The provided results have been tested for authenticity and it contributes to the literature, practical life, and policy-making subjects. Furthermore, it contributes to the improvement of the financial decisionmaking processes and enables the organization to make decisions to improve the accounting-based organizational performance. This study is a significant theoretical addition for defining the factors empirically that impacts the return on assets.

This study is closely focusing on the Impact of shortand long-term debt, which will significantly help out the firms make the right capital budgeting decisions. Practically, the success of companies mostly depends on the combination of equity and debt. This percentage decides the level of return on assets and equity [30]. This study significantly presents the impacts of the decisions regarding the involvement of debt in the business structure. The author has provided the literature-based evidence about financing decision ratios' importance to improve firm accounting-based performance. The different parts of this paper will include the review of literature of the past studies, the methodology of the study will be mentioned in the third section, the fourth section will comprise upon the analysis of this research, and the fifth section will comprise upon the discussion in the conclusion of this study.

\section{Literature review}

Impacts of total debt to total asset on return on assets

The income generated through the assets is profoundly affected by total debt to total asset. Return accounts debts of a company on Asset (Abubakar \& Management, 2015). It has been seen by different researchers that the relations that exist between the return on the assets and the total debt that is due by the side of the company (Abubakar \& Management, 2015; Adesina, Nwidobie, Adesina, \& research, 2015). The Energy and petroleum firms listed on the Nairobi Securities Exchange show a 0.721 correlation coefficient $(\mathrm{R})$, which predicts a strong positive relationship between return on asset and debt. Return on asset equals the net profit divided by the total assets. ROA shows the profitable a firm as compared to its total assets. Managers, investors, or analysts are kept aware by return on asset. It tells them whether a company's management is effectively utilizing its assets and producing earnings or not. Return on assets is displayed in the form of a percentage (Matos, Vairinhos, Selig, \& Edvinsson, 2019). When we compare a firm with other firms or compare a firm with its last performance, then return on assets is the best way to help. Not like other metrics such as ROE, return on assets considers the debt of the company. If we talk in simple terms, ROA is a measure of the earned amount of returns from a specific invested amount of assets [20]. Return on assets considerably differ for public companies and depends on the industry very much. When we use return on asset as a tool to compare, we should compare it with the previous return on asset of the company or against a similar company [29]. The company's effectiveness in changing the capital it invests into net income is shown by ROA figures to the investors.

Furthermore, the total liabilities and equity of shareholders collectively make the total assets. The corporation's operations are funded by assisting these two types 
(Dumay, La Torre, \& Farneti, 2019). A few predictors and investors ignore the cost of gaining the asset by adding back interest expenses in the formula for return on assets. The company's assets are provided by debt or equity [39]. The net income amount in the statement of income removes the interest expenditure. That is why the interest expense is added. The hypothesis derived is given as follows:

H1 Impacts of Total Debt to Total Asset on Return on Assets is significant.

Impacts of long-term debt to total asset on return on asset The asset's return has an inverse impact on Long-term debt to the accumulative number. The association between return on assets and LTDTA is negative with -0.672 of Pearson coefficient. When long-term debt increases, ROA is decreased. Businesses (at minimum, the ones that survive) are ultimately about productivity: enfolding the most out of fractional assets. Comparison of profits to revenue is a useful functioning metric, associating them to the possessions a company utilized to create them cuts to the real probability of its survival. [41]. Long-term debt is the debt that is due for more than one whole year. A few examples of long-term debt involve bonds and the government's treasuries can be observed previously [8,9]. The forms of debts are often written together as long-term debt below the non-current liabilities on the balance sheet. The long-term debt ratio should not be higher than that debt's worth way more than the assets' worth [16]. Undoubtedly, owed more than what is worthy of is not an honorable thing. The closer the ratio is to zero, the bigger the divisor is. However, the divisor is divided by amount, which, is an over-all asset amount. [45]. When a company has greater assets than it has debts, they are in a good position. As far as the company's long-term debt ratio is concerned, the share of the assets firm to liquidate to pay the long-term debts. It is a good thing always to have when seeing more significant financial decisions, as taking on a new credit or refinancing the debt from a new institute [42]. Higher return on asset specifies more efficiency of asset. The hypothesis derived is given as follows:

H2 Impacts of Long-Term Debt to Total Asset on Return on Asset is significant.

\section{Impacts of short-term debt to total asset on return on assets}

The return on the asset has a direct impacts of short-term debt to the total asset. According to
Abhayawansa, Guthrie, \& Bernardi, (2019), the energy and petroleum businesses present in the NSE have a 0.674 Pearson correlation coefficient of short-term debt to total assets and return on assets It shows that the more the ratio of short-term debt to total assets, the more the return on asset grasped by the businesses. The profitability of the firm varies in response to differences in the firms' liability maturity structure, with more confidence in short-term liabilities linked with higher profitability [6]. Short-term debt is the sum of a credit that should be paid to the lender for one year. On the balance sheet, this amount is viewed as a short-term liability. All other amounts overdue with extended reimbursement periods are stared at as long-term debt in the balance sheet. The output in the short-term debt account is the topmost contemplation when judging the liquidity of a firm. If the share of this debt to the number of liquid assets is very much, analysts may deduct that the firm experiences a liquidity problem and lessens its debt rating [31]. So, the hypothesis derived is given as follows:

H3 Impacts of Short-Term Debt to Total Asset on Return on Assets is significant.

\section{Impacts of total debt to total asset on return on equity}

Total debt to total asset influences the return on equity directly. Frequently, firms with a large debt ratio have a better Return on Equity (Alnori, Finance, \& Management, 2020). A substantial return on equity permits a firm to invest less of its capital to accomplish its growth goal and leaves the firm with more significant capital on hand to utilize either on share buyback or to pay a further Revenue. Similarly, as seen now, debts can precisely raise the return on Equity [21]. In contrast, a more significant debt advances a red flag for impoverishment. So, these plans can recover return on equity, but they do not generate long-term worth for the shareholders. Liability makes return on equity more significant as the equity of the shareholder goes down. So far, the return on equity created is ambiguous concerning how successfully the firm is being managed.

Return on equity is also a substance of proper management. The capital structure of a company consists of equity only or both equity and debt. Return on equity (ROE) is a mark of monetary demonstration evaluated by dividing net income by shareholders' equity. As equity of shareholders, return on equity is regarded as the return on net assets [36]. Return on equity works in how proficiently management is applying the company's assets to produce a profit. Return on equity (ROE) estimates how efficiently management uses a firm's 
assets to create profits. Whether a return on equity is regarded as suitable will depend on what is standard for the industry or firm peers. A second problem that can create a high return on equity is surplus debt [11, 25]. If a firm has been continuously borrowing, it can raise the return on equity as equity equals assets minus debt. The more debt a firm has, the smaller equity can fall. A typical situation is when a firm borrows vast volumes of debt to buy back its stocks. It can decrease earnings per share (EPS) [10], but it does not impacts actual performance or progress rates. So, the hypothesis derived is given as follows:

H4 Impacts of Total Debt to Total Asset on Return on Equity is significant.

\section{Impacts of long-term debt to total asset on return on equity}

Return on equity is affected by long-term debt negatively and significantly. There is a different association between LTDTA and ROE [40]. Greater long-term debt will result in the firm having difficulty paying its duties to suppliers and vice versa. LTDTA Ratio displays its financial scenario and the firm's aptitude to meet all its financial requirements. It demonstrates the percentage of a firm's assets backed with debts and other fiscal compulsions that last over one year [43]. Long-term debt is the utmost leading variable inducing return on equity. Think that a corporate with a higher Return on Equity is possibly one that can make cash within. The researcher ought to dig deeper into the investigation to determine how the firm's liability level Impact the return on equity
(Al-Sa'eed, 2018). So, the hypothesis derived is given as follows:

H5 Impacts of Long-Term Debt to Total Asset on Return on Equity is significant.

\section{Impacts of short-term debt to total asset on return on equity}

Return on equity is influenced by short-term debt to asset in a positive manner. It has a robust noteworthy effect on return on equity [38]. A business's market shortterm debt ratio (MSDR) is accurately defined to be book short-term debt divided by the market price of the firm. A firm's market worth is estimated as total assets minus book common equity added market common equity [24]. Firms that rely on short-term backing are more visible to liquidity dangers than those with longer-term liability finance as debt facilities can be inhibited at once. While firms with short-term support are likely to have a lower cost of debt than those with longer-term funding, should interest charges grow, those with short-term funding will see rates increasing. These firms must consider the short-term debt ratio, which will be essential further in the equity cycle [15]. So, the hypothesis derived is given as follows:

H6 Impacts of Short-Term Debt to Total Asset on Return on Equity is significant.

\section{Conceptual model of the study}

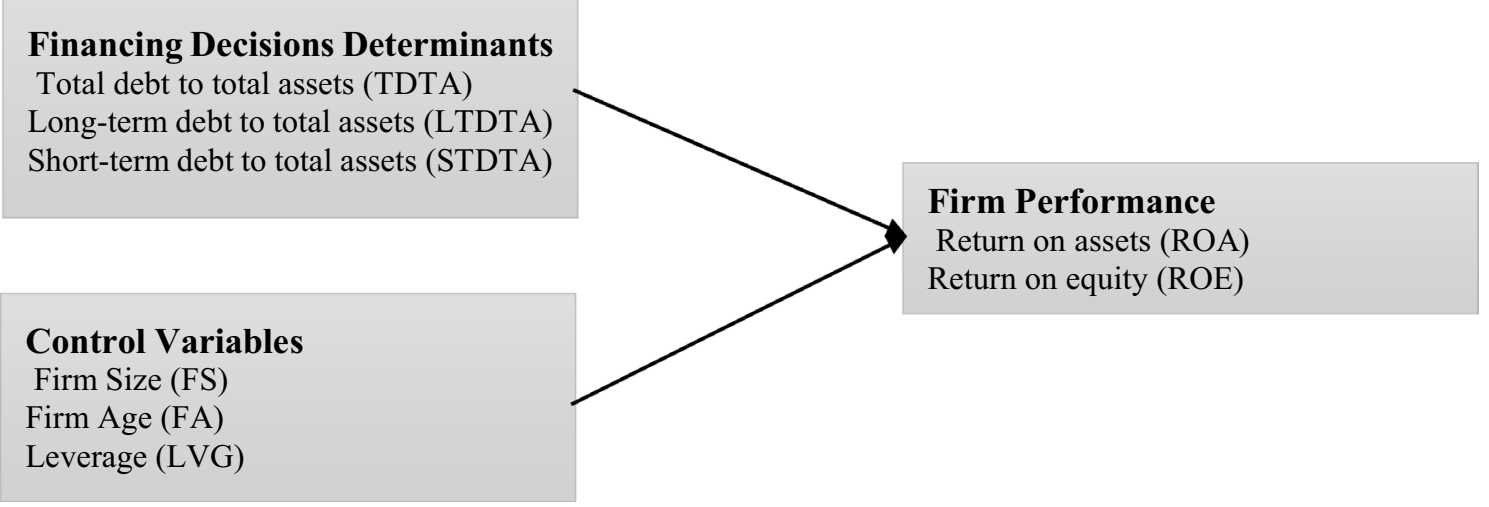




\section{Methods}

\section{Research approach}

The method used to collect the data is qualitative approach. The information discussed or mentioned is available in different authentic studies or books. For the bona fide information, data are gathered from the audited financial statements available publicly on Jordan's 40 listed firms.

The study has only used those firms which were listed before 2007 and are still being listed. The study has not collected data from different financial institutions like banks and insurance firms as those firms have the capital structure, which is different from this study's needs.

\section{Research techniques}

This research uses the generalized method of the moment or the GMM technique to know about the impacts cast by financing decisions ratios on firm accounting-based performance. This method gives the advantage of the solution to heteroscedasticity; it also removes autocorrelation [27]. Also, it avoids the existence of any potential endogenous [32]. The researcher has employed the return on assets and the factor of return on equity, which will indicate the firms' performance. In this study, the financing decisions have been involved by three indicators from the debt ratio, which are.

I. total debt to total assets

II. long-term debt to total assets

III. and short-term debt to total assets
Measures

\begin{tabular}{|c|c|c|}
\hline Variables & Measures & Sources \\
\hline \multicolumn{3}{|l|}{ Dependent Variables } \\
\hline Return on assets & $\begin{array}{l}\text { Net profit / Total } \\
\text { assets }\end{array}$ & $\begin{array}{l}\text { Aphagia and Gavoury } \\
\text { (2011) }\end{array}$ \\
\hline Return on Equity & $\begin{array}{l}\text { Net Income / Average } \\
\text { Total Equity }\end{array}$ & Odusanya et al. (2018) \\
\hline \multicolumn{3}{|l|}{ Independent Variables } \\
\hline $\begin{array}{l}\text { Total debt to total } \\
\text { assets (TDTA) }\end{array}$ & $\begin{array}{l}\text { Total debt / Total } \\
\text { assets }\end{array}$ & Daud et al. (2016) \\
\hline $\begin{array}{l}\text { Long-term debt to } \\
\text { total assets (LTDTA) }\end{array}$ & $\begin{array}{l}\text { Long-term debt / } \\
\text { Total assets }\end{array}$ & Hamid et al. (2015) \\
\hline $\begin{array}{l}\text { Short-term debt to } \\
\text { total assets (STDTA) }\end{array}$ & $\begin{array}{l}\text { Short-term debt / } \\
\text { Total assets }\end{array}$ & Malik (2011) \\
\hline \multicolumn{3}{|l|}{ Control variables } \\
\hline Firm Size & $\begin{array}{l}\text { Natural logarithm of } \\
\text { turnover }\end{array}$ & $\begin{array}{l}\text { Ghayas and Akhter } \\
\text { (2018) }\end{array}$ \\
\hline Firm Age & $\begin{array}{l}\text { Natural logarithm of } \\
\text { the number of years } \\
\text { since the establish- } \\
\text { ment of the firm }\end{array}$ & Ogebe et al. (2016) \\
\hline Leverage & $\begin{array}{l}\text { \% of total debts } \\
\text { divided by \% of } \\
\text { total assets }\end{array}$ & $\begin{array}{l}\text { Ameen and Shahzadi } \\
\text { (2017) }\end{array}$ \\
\hline
\end{tabular}

So, the research model is estimated with the use of the equations generated below:

\section{For ROA:}

$$
\begin{aligned}
R O A_{i t} & =\beta_{0}+\beta_{1} \text { TDTA }_{i t}+\beta_{2} F S_{i t}+\beta_{3} F A_{t} \\
& +\beta_{4} L V G_{t}+\varepsilon_{i t}(\text { Model } 1) \\
R O A_{i t} & =\beta_{0}+\beta_{1} L T D T A_{i t}+\beta_{2} F S_{i t} \\
& +\beta_{3} F A_{t}+\beta_{4} L V G_{t}+\varepsilon_{i t}(\text { Model } 2) \\
R O A_{i t} & =\beta_{0}+\beta_{1} S T D T A_{i t}+\beta_{2} F S_{i t}+\beta_{3} F A_{t} \\
& +\beta_{4} L V G_{t}+\varepsilon_{i t}(\text { Model } 3)
\end{aligned}
$$

\begin{tabular}{|c|c|c|c|c|c|c|}
\hline Variable & Mean & Median & Maximum & Minimum & Std. Dev & Observations \\
\hline $\mathrm{ROA}$ & -0.0244 & 0.0028 & 0.3607 & -1.9530 & 0.1750 & 200 \\
\hline ROE & -0.1241 & 0.0050 & 0.5085 & -11.4973 & 0.9145 & 200 \\
\hline TDTA & 0.3538 & 0.3073 & 3.6603 & 0.0040 & 0.3376 & 200 \\
\hline STDTA & 0.3138 & 0.2582 & 3.6603 & 0.0040 & 0.3250 & 200 \\
\hline LTDTA & 0.0401 & 0.0000 & 0.5515 & 0.0000 & 0.0841 & 200 \\
\hline FSIZE & 14.3026 & 16.0850 & 20.4358 & 0.0000 & 5.3868 & 200 \\
\hline FAGE & 32.9550 & 27.0000 & 98.0000 & 5.0000 & 17.3719 & 200 \\
\hline LEVERAGE & 0.9241 & 0.4305 & 16.3002 & -3.0822 & 2.1853 & 200 \\
\hline
\end{tabular}

Table 1 Descriptive statistics

Above is the table of descriptive statistics, which is showing the data that was collected from the 40 Jordan listed firms. It can be seen that the data lie in between the valid maximum and minimum value range. Moreover, the standard deviation values are low and show that the data is least skewed 
For ROE:

$$
\begin{aligned}
& R O E_{i t}=\beta_{0}+\beta_{1} T D T A_{i t}+\beta_{2} F S_{i t}+\beta_{3} F A_{t}+\beta_{4} \overline{L V G_{t}+\varepsilon_{i t}(\text { Model } 1)} \\
& R O E_{i t}=\beta_{0}+\beta_{1} L T D T A_{i t}+\beta_{2} F S_{i t}+\beta_{3} F A_{t}+\beta_{4} L V G_{t}+\varepsilon_{i t}(\text { Model } 2) \\
& R O E_{i t}=\beta_{0}+\beta_{1} S_{D T T A}+\beta_{2} F S_{i t}+\beta_{3} F A_{t}+\beta_{4} L V G_{t}+\varepsilon_{i t}(\text { Model 3) }
\end{aligned}
$$

The equations mentioned above results in three models for both returns on the assets and return on the equity. These models have represented.

Return on assets (ROA)

Return on Equity (ROE)

Total debt to total assets (TDTA)

Long-term debt to total assets (LTDTA)

Short-term debt to total assets (STDTA)

Firm size (FS)

Leverage (LVG)

Firm age (FA)
The symbol $\beta$ represents the values of the coefficient for each variable understudy, representing the value of the impact of the independent variables on the dependent variables. These models will also represent the impacts of the control variables and their Impact on the dependent variables.

\section{Empirical findings \\ Descriptive statistics

\begin{tabular}{|c|c|c|c|c|c|c|c|c|}
\hline \multicolumn{9}{|c|}{ Correlation } \\
\hline t-Statistic & $\mathrm{ROA}$ & $\mathrm{ROE}$ & TDTA & STDTA & LTDTA & FSIZE & FAGE & Leverage \\
\hline \multirow[t]{2}{*}{$\mathrm{ROA}$} & 1.0000 & & & & & & & \\
\hline & - & & & & & & & \\
\hline \multirow[t]{2}{*}{$\mathrm{ROE}$} & 0.5647 & 1.0000 & & & & & & \\
\hline & 9.6285 & -53 & & & & & & \\
\hline \multirow[t]{2}{*}{ TDTA } & -0.1693 & -0.1895 & 1.0000 & & & & & \\
\hline & -2.4172 & -2.7152 & - & & & & & \\
\hline \multirow[t]{2}{*}{ STDTA } & -0.1847 & -0.2058 & 0.9685 & 1.0000 & & & & \\
\hline & -2.6441 & -2.9594 & 54.7406 & - & & & & \\
\hline \multirow[t]{2}{*}{ LTDTA } & 0.0341 & 0.0349 & 0.2712 & 0.0230 & 1.0000 & & & \\
\hline & 0.4806 & 0.4913 & 3.9648 & 0.3243 & - & & & \\
\hline \multirow[t]{2}{*}{ FSIZE } & 0.2447 & 0.1927 & 0.0948 & 0.0673 & 0.1202 & 1.0000 & & \\
\hline & 3.5506 & 2.7635 & 1.3396 & 0.9496 & 1.7043 & - & & \\
\hline \multirow[t]{2}{*}{ FAGE } & 0.0438 & -0.0208 & -0.0291 & -0.0592 & 0.1122 & 0.2726 & 1.0000 & \\
\hline & 0.6174 & -0.2921 & -0.4091 & -0.8347 & 1.5892 & 3.9864 & - & \\
\hline \multirow[t]{2}{*}{ Leverage } & -0.2259 & -0.6183 & 0.3315 & 0.2381 & 0.4106 & -0.0923 & -0.0214 & 1.0000 \\
\hline & -3.2623 & -11.071 & 4.9435 & 3.4490 & 6.3373 & -1.3038 & -0.3018 & - \\
\hline
\end{tabular} \\ Table 1}

Table 2 Correlation test

Table 3 Diagnostics test for ROA model

\begin{tabular}{lllll}
\hline Test & Method & Model 1 & Model 2 & Model 3 \\
\hline Heteroscedasticity & MWBP/CW X2-value & $6.38^{* *} / 5.484^{* *}$ & $9.13^{* *} / 4.279^{* *}$ & $4.39^{* *} / 4.02^{* *}$ \\
autocorrelation & Wooldridge F-statistic: & $7.48^{*}$ & $6.93^{*}$ & $5.574^{*}$ \\
CD dependence & Pesaran Test statistic: & $3.38^{*}$ & $2.028^{*}$ & $2.388^{*}$ \\
Multidisciplinary & Mean VIF & 1.93 & 2.19 & 2.94 \\
\hline
\end{tabular}

*Indicates Significance level 0.05 and ** Indicates Significance level 0.01 


\section{Correlation test}

Table 2 above shows the correlation coefficients among all of the variables. The table above shows that the correlation between ROA and TDTA, STDTA, and LVG is negative, which shows that the relationship is negative. While the correlation of ROA with LTDTA, ROE, FSIZE, and FAGE is significant and positive. The correlation between ROE and TDTA, STDTA, FAGE, and LVG is significant and negative, whereas the correlation of ROE with LTDTA and FSIZE is significant and positive. The correlation of TDTA is significant and negative with FAGE, except all others have a significant positive correlation, whereas there is no correlation with ROE. The correlation of STDTA with FAGE, ROA, and ROE is significant and negative, whereas there is a positive and significant correlation between STDTA and LTDTA, FSIZE, and LVG. The correlation between LTDTA and FSIZE, FAGE, LVG, ROA, ROE, and TDTA is significant and positive. The correlation between FSIZE and LVG is negative and significant, whereas, with all of the other variables, the correlation is significant and positive. The correlation of FAGE with LVG, ROE, TDTA, and STDTA is significant and negative, whereas the correlation with ROA, LTDTA, and FSIZE is significant and positive. The correlation between LVG and ROA, ROE, FSIZE, and FAGE

Table 4 GMM estimation for ROA model

\begin{tabular}{llll}
\hline Dependent Variable $=$ ROA & Model 1 & Model 2 & Model 3 \\
\hline TDTA & $-0.0738^{*}$ & - & - \\
STDTA & - & $-0.088^{* *}$ & - \\
LTDA & - & - & $0.2422^{* *}$ \\
FAGE & -0.0030 & -0.0031 & -0.0003 \\
FSIZE & $0.0084^{*}$ & $-0.0081^{*}$ & $0.0070^{*}$ \\
Leverage & $-0.012^{* *}$ & $-0.0131^{* *}$ & $-0.0203^{* *}$ \\
Constant & $-0.093^{* *}$ & $-0.0884^{* *}$ & $-0.1047^{* *}$ \\
$R^{2}$ & $0.1286^{* *}$ & $0.1093^{* *}$ & $0.1128^{* *}$ \\
Arellano-Bond test for AR (1) (Pr & 0.0367 & 0.0431 & 0.0271 \\
$\quad$ W z) & & & \\
Arellano-Bond test for AR (2) (Pr & 0.1388 & 0.8357 & 0.3977 \\
$\quad$ W ) & & & \\
Sargan test of overid restrictions & 0.9367 & 0.0774 & 0.0355 \\
\hline
\end{tabular}

*Indicates Significance level 0.05 and ** Indicates Significance level 0.01
Table 6 GMM estimation for ROA model

\begin{tabular}{llll}
\hline Dependent Variable $=$ ROE & Model 1 & Model 2 & Model 3 \\
\hline TDTA & $-0.0185^{* *}$ & - & - \\
STDTA & - & $-0.2328^{* *}$ & - \\
LTDA & - & - & $3.7165^{* *}$ \\
FAGE & $-0.0040^{*}$ & $-0.0044^{*}$ & -0.0055 \\
FSIZE & $0.0269^{*}$ & $0.0283^{* *}$ & $0.0188^{* *}$ \\
Leverage & $-0.2523^{* *}$ & $-0.2448^{* *}$ & $-0.3141^{* *}$ \\
Constant & $-0.1359^{* *}$ & $-0.0853^{* *}$ & $-0.0695^{* *}$ \\
$R^{2}$ & $0.4064^{* *}$ & $0.04127^{* *}$ & $0.4996^{* *}$ \\
Arellano-Bond test for AR (1) (Pr & 0.0587 & 0.0473 & 0.02765 \\
$\quad \begin{array}{l}\text { W z) } \\
\text { Arellano-Bond test for AR (2) (Pr }\end{array} \quad 0.4871$ & 0.9367 & 0.5465 \\
$\quad \begin{array}{l}\text { W } \text { ) } \\
\text { Sargan test of overid restrictions }\end{array}$ & 0.1873 & 0.2377 & 0.2670 \\
\hline *Indicates Significance level 0.05 and ** Indicates Significance level 0.01
\end{tabular}

is significant and negative, whereas the correlation with TDTA, STDTA, and LTDTA is significant and positive.

\section{Diagnostics test for ROA model}

In above Table 3, it can be seen that their multidisciplinary exists in all of the three models. It explained that all of the models consist of autocorrelation and heteroscedasticity. Thus, GMM is a tool to remove or control heteroscedasticity, autocorrelation, or potential endogenous problems [28].

\section{GMM estimation for ROA model}

It can be seen that the impacts of TDTA on ROA is significant and negative, so ROA will decrease by $7.3 \%$ with every $1 \%$ increase in TDTA, the impacts of STDTA on ROA is significant and negative so that ROA will decrease by $8.8 \%$ with every $1 \%$ increase in STDTA. The impacts of LTDTA is positive and significant on ROA. There is no impacts of FA on ROA, and there is a significant and positive impacts of FS, whereas the impacts of leverage is negative and significant (Tables $4,5,6$ )

Table 5 Diagnostics test for ROE model

\begin{tabular}{|c|c|c|c|c|}
\hline Test & Method & Model 1 & Model 2 & Model 3 \\
\hline Heteroscedasticity & MWBP/CW $\times 2-$ value & $8.47^{* *} / 6.58^{* *}$ & $7.83^{* *} / 5.27^{*}$ & $5.10^{* *} / 5.01^{* *}$ \\
\hline Autocorrelation & Wooldridge F-statistic: & $8.77^{* *}$ & $5.38^{*}$ & $6.01^{*}$ \\
\hline CD dependence & Pesaran Test statistic: & $2.48^{* *}$ & $2.07^{*}$ & $2.12^{*}$ \\
\hline Multicollinearity & Mean VIF & 1.57 & 1.378 & 1.67 \\
\hline
\end{tabular}

*Indicates Significance level 0.05 and ** Indicates Significance level 0.01 


\section{Diagnostics test for ROE model}

It explained that all of the models consist of autocorrelation and heteroscedasticity. Thus, GMM help to remove or control heteroscedasticity, autocorrelation, or potential endogenous problems.

\section{GMM estimation for ROA model}

The impacts of TDTA on ROE are significant and negative, as shown above; the same is the case for STDTA, whereas the impacts of LTDTA on ROE are significant and positive. There is a significant and negative impacts in the short and long term of FA on ROE; FS's impacts are significant and positive. At the same time, the impacts of LVG are negative and significant on ROE.

\section{Result and discussion}

This research aimed to know the impacts of total debt on total assets, long-term debt to total assets, shortterm debt to total assets on return on assets, and equity return. This research also inculcated firm size, firm age, and leverage in the study to know their impacts on return on assets and return on equity. The researcher used various latest techniques for analysis of the data, and the results will be discussed in this portion one by one. The first hypothesis proposed in this research was approved and the same results have also been supported by Morellec, Nikolov, \& Zucchi, (2014). The impacts are seen to be negative and significant. The second hypothesis proposed by the study was accepted by the study of (Adesina, Nwidobie, \& Adesina, 2015), and the impacts are seen to be negative and significant. The third hypothesis proposed by the study was approved. It shows that the impacts are positive and significant, whereas this result is supported by the study $[8,9]$. The fourth hypothesis proposed by the study was accepted, and the same results are also supported by the study of [44]. The fifth hypothesis proposes that the impacts are negative and significant and it has been approved. The sixth hypothesis proposed was accepted and acknowledged by the study as well.

\section{Conclusion}

To know about the impacts of financing decision ratios on firm accounting-based performance, the researcher collected 40 listed firms of Jordan; the study only took those firms who have been listed since 2007 till now. The firm also collected data from the website of the World Bank for this study. Two hundred observations were made and, on those observations, the generalized method of moment technique was applied for the analysis of data. Different measures were used to measure the variables. The results showed that the impacts of total debt to total assets, long-term debt to total assets, and short-term debt to total assets are significant on both returns on assets and return on equity. It was also seen that firm size, firm age, and leverage also play a significant role as control variables. According to the author, it is a theoretical addition for defining the factors empirically that impacts the return on assets that previous studies have not properly addressed.

Furthermore, the study is closely focusing on the Impact of short- and long-term debt, which will significantly help out the firms make the right capital budgeting decisions. Practically, the success of companies mostly depends on the combination of equity and debt. This percentage decides the level of return on assets and equity. This study significantly presents the impacts of the decisions regarding the involvement of debt in the business.

\section{Implications of the study}

The study has significant implications for the authorities as according to the study results. It is suitable to advise the authorities to keep inflation acceptable and make policies accordingly. The authorities will stabilize the economy and improve the financial industry and the banking industry, where the companies and their customers will enjoy lower interest rates. The companies will have better liquidity as well. This study's findings will help the firm increases its operations, reduce its input cost, and improve its performance while gaining productivity.

This study has increased the overall importance of financing decision ratios where it comes to firm accounting-based performance, which will be more focused when it comes to the enhancement of financial- and accounting-based efficiency. Moreover, practically the research has given the higher authorities any idea about how they should recognize financing decisions and ratios in boosting their company's overall performance. It has been observed that there is a negative association between total debt assets and the factors of return on assets and on equity. It ultimately shows the impact on the company's performance. All of this discussion is useful for higher authorities to cut down their debt in the capital structure.

\section{Limitations and future research recommendations}

However, the study has its limitations; the researcher has only taken ROA to measure the overall firm accountingbased performance. There are many other factors which directly contribute in enhancing or lowering the firm's accounting-based performance. That is why, the author recommends the future researchers consider more factors for measuring the firm's accounting-based performance. The researcher recommends the future researchers add factors like return ROI, gross profit margin, net profit margin, return on capital employed next time. 


\section{Abbreviations}

STDTA: short-term debt to total assets; LTDTA: long-term debt to total assets; TDTA: total debt to total assets; ROA: return on assets; ROE: return on equity; LVG: leverage; FA: firm age; FS: firm size.

\section{Acknowledgements}

Not applicable.

\section{Authors' contributions}

No authors contributions.

\section{Funding}

This research no external funding.

\section{Availability of data and materials}

All data used in the study were downloaded from the Amman Stock Exchange (Companies Guide) through the following link: https://www.ase.com.jo/ar/ history?history_category $=64$

\section{Declarations}

\section{Competing interests}

The authors declare no conflict of interest.

Received: 1 October 2020 Accepted: 29 March 2021

Published: 28 April 2021

\section{References}

1. Abhayawansa S, Guthrie J, Bernardi C (2019) Intellectual capital accounting in the age of integrated reporting: a commentary. J Intel Capital

2. Abu-Rub N (2012) Capital structure and firm performance: evidence from Palestine stock exchange. J Money Invest Bank 23(1):109-117

3. Abubakar AJIJOE, Commerce, \& Management (2015) Relationship between financial leverage and financial performance of deposit money banks in Nigeria 3(10): 759-778.

4. Adesina JB, Nwidobie BM, Adesina $O O$ (2015) Capital structure and financial performance in Nigeria. Int J Bus Soc Res 5(2):21-31

5. Adesina JB, Nwidobie BM, Adesina OOJIJOb, Research S (2015) Capital structure and financial performance in Nigeria 5(2): 21-31.

6. Agrawal AK, Matsa DA (2013) Labor unemployment risk and corporate financing decisions. J Financ Econ 108(2):449-470

7. Al-Matari EM, Al-Swidi AK, Fadzil FH, Al-Matari YA (2012) The Impacts of board characteristics on firm performance: Evidence from nonfinancial listed companies in Kuwaiti Stock Exchange. Int J Account Financ Report 2(2):310-332

8. Al-Najjar B (2015) Does ownership matter in publicly listed tourism firms? Evidence from Jordan. Tour Manage 49:87-96

9. Al-Najjar BJTM (2015) Does ownership matter in publicly listed tourism firms? Evidence Jordan 49:87-96

10. Al-Rdaydeh M (2018) Moderating effect of competitive strategies on the relationship between financial leverage and firm performance: Evidence from Jordan. Bus Econ Horizons 14(3):626-641

11. Al-Rdaydeh MJB, Horizons E (2018) Moderating effect of competitive strategies on the relation between financial leverage and firm performance: Evidence from Jordan 14(3):626-641

12. Al-Sa'eed M, t. A. A. (2018) The Impacts of ownership structure and dividends on firm's performance: evidence from manufacturing companies listed on the amman stock exchange. Aust Account Bus Finance J 12(3):107-126

13. Alfaraih $M$, Alanezi $F$, Almujamed $H$ (2012) The influence of institutional and government ownership on firm performance: evidence from Kuwait. Int Bus Res 5(10):192

14. Alnori FJIJOI, Finance ME, Management (2020) Cash holdings: Do they boost or hurt firms' performance? Evidence from listed non-financial firms in Saudi Arabia.

15. Alzoubi ESS (2018) Audit quality, debt financing, and earnings management: evidence from Jordan. J Int Account Audit Tax 30:69-84
16. Aschbacher MC, Sablik J (2019) Innovative leadership style for industrial companies. Sci J Bus Manag 7(2):45

17. Bessler W, Drobetz W, Grüninger MC (2011) Information asymmetry and financing decisions. Int Rev Financ 11(1):123-154

18. Brondoni SM (2020) Shareowners, stakeholders \& the global oversize economy. The coca-cola company case. Symp Emerg Issues Manag 1:16-27

19. Chandra P (2020) Fundamentals of financial management. McGraw-Hill Education, London

20. Dong M, Hirshleifer D, Teoh SH (2012) Overvalued equity and financing decisions. Rev Financ Stud 25(12):3645-3683

21. Drobetz W, Gounopoulos D, Merikas A, Schröder H (2013) Capital structure decisions of globally-listed shipping companies. Transp Res Part E Logist Transp Rev 52:49-76

22. Dumay J, La Torre M, Farneti F (2019) Developing trust through stewardship. J Intell Capital

23. Hanousek J, Shamshur A (2011) A stubborn persistence: Is the stability of leverage ratios determined by the stability of the economy? J Corp Finan 17(5):1360-1376

24. Hull RM, Dawar V (2014) Agency theory, capital structure and firm performance: some Indian evidence. Managerial Finance.

25. Husain U, Javed S (2019) Stock price movement and volatility in muscat security market (MSM). Int J Res Granthaalayah 7(February):68-84. https:// doi.org/10.5281/zenodo.2580535

26. Javed S, Atallah B, Aldalaien E, Husain U (2019) Performance of venture capital firms in UK: quantitative research approach of 20 UK venture capitals. Middle-East J Sci Res 27(5):432-438. https://doi.org/10.5829/ idosi.mejsr.2019.432.438

27. Javed S, Husain O (2020) An ARDL investigation on the nexus of oil factors and economic growth: a timeseries evidence from Sultanate of Oman. Cogent Econ Finance 8(1):17. https://doi.org/10.1080/23322039.2020.1838418

28. Javed S, Husain U, Ali S (2020) Relevancy of investment decisions and consumption with asset pricing: GMM And CCAPM model approach. Int J Manag 11(8):10-17. https://doi.org/10.34218/IJM.11.8.2020.002

29. Javeed SA, Lefen $L$ (2019) An analysis of corporate social responsibility and firm performance with moderating effects of CEO power and ownership structure: a case study of the manufacturing sector of Pakistan. Sustainability 11(1):248

30. Khan AA, Javed S (2017) Accounting of post merger financial performance of Punjab National Bank (PNB) and Nedungadi Bank. Int J Mech Eng Technol 8(11):1043-1062

31. Khatoon T, Hossain M (2017) Capital structure and firm's financial performance: evidence from listed cement companies of Dhaka stock exchange of Bangladesh. Int J Bus Stat Anal 4(01):29-37

32. Leary MT, Roberts MR (2014) Do peer firms affect corporate financial policy? J Financ 69(1):139-178

33. Matos F, Vairinhos V, Selig, P M, Edvinsson L (2019) Intellectual capital management as a driver of sustainability. Springer, Berlin.

34. Moldovan N-C, Vătavu S, ALBU, C., PANAIT, R., \& STANCIU-MANDRULEANU, C. (2016) Corporate financing decisions and performance in times of crisis: threat or challenge? Econ Comput Econ Cybernet Stud Res 50:2

35. Morellec E, Nikolov B, Zucchi F (2014) Competition, cash holdings, and financing decisions. Swiss Finance Institute Research Paper (13-72).

36. Mumtaz R, Rauf SA, Ahmed B, Noreen U (2013) Capital structure and financial performance: evidence from Pakistan (Kse 100 Index). J Basic Appl Sci Res 3(4):113-119

37. Nikolaou IE (2019) A framework to explicate the relationship between CSER and financial performance: An intellectual capital-based approach and knowledge-based view of firm. J Knowl Econ 10(4):1427-1446

38. Northouse PG (2018) Leadership: theory and practice. Sage Publications, London

39. Salim M, Yadav R (2012) Capital structure and firm performance: Evidence from Malaysian listed companies. Procedia Soc Behav Sci 65:156-166

40. Serôdio PM, McKee M, Stuckler D (2018) Coca-Cola-a model of transparency in research partnerships? A network analysis of Coca-Cola's research funding (2008-2016). Public Health Nutr 21(9):1594-1607

41. Serrasqueiro Z, Nunes PM (2012) Is age a determinant of SMEs'financing decisions? Empirical evidence using panel data models. Entrep Theory Pract 36(4):627-654

42. Sun J, Ding L, Guo JM, Li (2016) Ownership, capital structure and financing decision: evidence from the UK. Br Account Rev 48(4):448-463 
43. Taani K (2013) The relationship between capital structure and firm performance: evidence from Jordan. Global Adv Res J Manag Bus Stud 2(11):542-546

44. Vintila G, Nenu EA (2015) An Analysis of determinants of corporate financial performance: evidence from the bucharest stock exchange listed companies. Int J Econ Financ Issues 5:3

45. Weshah SR, Dahiyat AA, Awwad MRA, Hajjat ES (2012) The Impacts of adopting corporate social responsibility on corporate financial performance: evidence from Jordanian banks. Interdisc J Contemp Res Bus 4(5):34-44

\section{Publisher's Note}

Springer Nature remains neutral with regard to jurisdictional claims in published maps and institutional affiliations.

\section{Submit your manuscript to a SpringerOpen ${ }^{\odot}$ journal and benefit from:}

- Convenient online submission

- Rigorous peer review

- Open access: articles freely available online

- High visibility within the field

- Retaining the copyright to your article

Submit your next manuscript at $\boldsymbol{\nabla}$ springeropen.com 